\title{
The Dutch
}

\section{Edward Duyker}

Dutch colonial ambitions and trading interests in the East Indies led to the first European visits to the Australian coast. Between 1606 and 1642, the Dutch charted most of the continent's northern, western and southern coasts. The Netherlands did not colonise Australia, but Dutch people in small numbers were present from 1788 onwards. Cornelius Du Heg, a seaman on the First Fleet transport Friendship, was possibly the first Dutchman to visit Port Jackson.

\section{The Dutch in the penal colony}

The first Dutch settlers in Sydney had emigrated to England and committed crimes there, resulting in their transportation. Many Dutch names are visible in the convict indents beginning with Jane Vandebus on the Second Fleet and John Vandiest transported on the Third Fleet. A number were Dutch Jews. Almost all were transported for stealing. Possibly the last Dutch convict to be transported to New South Wales was Haan Hartog (born c.1828) who was convicted in Birmingham of stealing cigars and sentenced to seven years transportation. He arrived on the Hashemy in June 1849.

\section{Early trade with the Dutch}

In October 1790, the chartered Dutch brig Waakzaamheid (referred to in British sources as the Waaksemheyd) brought desperately needed supplies from Batavia to the colonists. The Dutch master of this vessel gave convict William Bryant a compass, quadrant, charts and information on the sea route to Java. Soon after, Bryant, his wife Mary and other convicts made a daring escape in a fishing boat. They managed to sail all the way to Koepang in Timor, but their brave attempt was foiled when the Dutch authorities did not believe their claim to be shipwrecked mariners.

In 1795 the Netherlands was conquered by the French revolutionary armies and annexed by Napoleon; consequently the colonists of New South Wales became embroiled in a war with the Dutch to their north. A Dutch ship named the Swift was captured by the whaler Policy on 12 September 1804 and taken to Sydney. After the fall of Napoleon, shipping contacts with the Dutch in the Indies were re-established, but trade did not flourish.

Beginning with the Eugenia in December 1812, only 13 ships sailed from or via Batavia to Sydney until February 1825. They carried mainly foodstuffs. This number is in marked contrast with the 84 ships which sailed to Batavia from Sydney between January 1814 and October 1825, although virtually all carried only ballast or deadweight cargoes such as cut stone or coal. The tariff policies of competing Dutch and British colonial empires were not designed to expand trade between their respective satellites. The Dutch were fearful of the rise of Singapore as a British free port, so imposed restrictive tariffs against European (basically British) goods in 1823. A 
reciprocal trade agreement was formulated in 1824, but its interpretation was challenged in September 1838 and for a time Dutch ships were banned from New South Wales ports.

\section{The traveller's view}

An early Dutch writer on Sydney in the 1840s was P van Os, author of Reis naar Nieuw-ZuidWallis Uit het dagboek van een scheeps-doctor voor de jeugd berwekt [A Voyage to New South Wales from the journal of a Ship's Doctor edited for children]. This book is a curious semifictional work and although it is unclear whether van Os ever visited Sydney personally, he provided a glowing account of its cleanliness and its 'beautiful rows of houses, beautiful big hospitals and hotels'. He was less flattering in his description of Sydney's women and their slavish devotion to all things British and of the snobbishness of Sydney society which he considered highly polarised between free settlers and the emancipated.

Colonial censuses before 1871 give no figures for Dutch-born settlers. However, the Dutch settlers naturalised in New South Wales between 1845 and 1905 mostly arrived during the peak gold rush years 1851 to 1861 and all but one were male. They waited about 20 years before being naturalised and there is no accurate information on their original professions. From family historical sources, it seems that the majority of Dutch diggers were mariners who jumped ship in Australia. About 80 per cent of Dutch immigrants naturalised before 1905 came from coastal towns.

\section{The Dutch and Sydney in the first half of the twentieth century}

The Dutch colonial presence in the Indonesian archipelago played a role in developing shipping, telegraph and aviation links between Sydney, Asia and Europe, while also stimulating a small trickle of immigrants. In 1908, the Dutch Koninklijke Pakketvaart Maatschappij (KPM) navigation company set up a monthly steamer service between Batavia and Sydney.

In September 1910, the Dutch fleet visited Sydney. The Sydney Morning Herald reported the many civic and social functions that the Dutch sailors attended and included an article on Dutch exploration of Australia. The Dutch were the toast of the town. A pontoon was placed beside the flagship De Ruyter and over the weekend of 17-18 September, some 5000 Sydneysiders were shown over the ship by petty officers assisted by English-speaking crew members.

Developments in Dutch aviation also had important communications benefits for Sydney. In September 1929, Royal Dutch Airlines (KLM) inaugurated the Amsterdam-Batavia service with a three-engined Dutch Fokker F.VIIb that required 89 flying hours and the use of over 18 airfields to make the journey. In 1931 KLM flew mail from Amsterdam to Batavia; it was then taken to Sydney by the Royal Netherlands Indies Airlines (KNILM). 


\section{The Dutch and Sydney in World War II}

World War II and the displacement of the Dutch in the Indonesian archipelago led to the presence of Dutch military personnel, refugees and naval and merchant vessels in Sydney. Twenty-eight Dutch Koninklijke Pakketvaart Maatschappij (KPM) ships were based in Sydney and provided a critical contribution to the transport and supply of Australian and United States troops in New Guinea during 1942-3. For a time a pair of aging Dutch submarines were also based in Sydney and one was damaged during the Japanese raid on Sydney Harbour. On 5 June 1942, a Dutch B25 Mitchell bomber based in Canberra sank the Japanese submarine believed to have released the midget submarines which carried out the raid. The Netherlands Society in Sydney has its origins in a canteen established for Dutch servicemen in 1944.

\section{Postwar immigration}

The economic shambles of the Netherlands after World War II produced mass emigration to Australia which peaked at 160,369. The Dutch Government's sponsorship of voluntary emigration was further streamlined by the signing of the historic Netherlands Australia Migration Agreement (NAMA) on 22 February 1951. It applied to all classes of skilled and unskilled emigrants, and Australia contributed to the cost of passage. In the 1950s, as a result of the scheme, the Dutch came to Sydney in their thousands - mainly crowded on proud old vessels such as the Johan van Oldenbarnevelt, the Volendam and the Talisse. Many also came by air on KLM charter flights.

Many Dutch settlers in Sydney were initially accommodated in camps outside the city (in the Illawarra, Newcastle and Bathurst) and then settled in outlying suburbs such as Hornsby, Bankstown and Sutherland. Dutch residents who found temporary accommodation in the Lakeside Caravan Park at Narrabeen originated the Dutch Australian Society Neerlandia in March 1954. This society endured after the residents folded their tents and moved into proper houses. The camps and hostels helped to forge enduring personal friendships. Johannes 'Harry' Vandenberg (born 1947), better known as Harry Vanda, met Scottish-born George Young in Sydney’s Villawood Migrant Hostel in 1964 and together with Englishman Stevie Wright and another Dutch immigrant Dingernam Vandersluys (Dick Diamonde), formed the highly successful group the Easybeats. Their song Friday on My Mind made them international stars and at the close of the twentieth century was voted the best Australian song of all time by the Australasian Performing Rights Association (APRA).

When the Dutch Government encouraged thousands of Dutch citizens to quit their homeland and settle in Australia, they were expected to lose their 'Dutchness'. At first many Dutch tried to fulfil this expectation, but ultimately found the process spiritually numbing and became increasingly aware of the unique value of their heritage. Although Dutch immigration to Australia was mainly 
a phenomenon of the 1950s and early 1960s, many Dutch organisations did not come into existence until cultural diversity began to be celebrated from the late 1960s onwards. In Sydney, for example, Dutch clubs in the Hawkesbury, St Marys and Hornsby districts were formed in 1968, 1978 and 1983 respectively.

As the Dutch-born in Sydney have aged, they have had to deal with specific community problems. As early as 1970 a committee was formed to raise funds for a Dutch retirement village in the Sutherland Shire. Between 1972 and 1978, seven Hollandse Kermis (Mardi Gras-like festivals) were held to raise seed money for the purchase of land in Miranda and with private, community and government funds, the Juliana Village, designed by Danish-born architect Leif Kristensen, was officially opened in November 1980. This comprises 84 units, a library, office, boardroom, leisure centre, hairdressing salon and billiard room. The Juliana Village Association inspired other Dutch organisations and communities to solve the problems of their elderly members. In Blacktown, for example, the largely Dutch members of the Reformed Churches built the Eureka Retirement Homes opposite their church. Two other retirement villages have been constructed in the greater Sydney region: the Abel Tasman Village in Chester Hill and the Queen Beatrix Village in Albion Park. The Dutch community in New South Wales has also formed a committee to establish a nursing home and created several suburban and regional social welfare Instutfgroepen (sub-committees) under the umbrella of the Federation of Netherlands Societies. Members feel a certain degree of urgency because of the many thousands of Dutch-born Sydneysiders now in their 70s and 80s.

\section{Dutch language in Sydney}

Despite the poor level of language retention among the descendants of the Netherlands-born, Dutch remains an important community language in Sydney. In 2002 a new Dutch syllabus was introduced to the New South Wales Higher School Certificate. However, the number of students sitting for Dutch exams at the end of high school has steadily declined. Undergraduate courses in the Dutch language have also been terminated in Australian universities because of falling enrolments, but in Sydney, Dutch is taught by the Saturday School of Community Languages, the Workers Educational Association and to a group of Dutch-speaking primary school children attending the Stichting Nederlandse School 'De Kangaroo’ in Gordon.

\section{Dutch media in Sydney}

The Dutch community in Sydney has supported a modest Dutch language press. The Sydneybased Dutch Australian Weekly was founded in 1951 by Alfred Schuurman with the assistance of Cumberland Newspapers. However, Dutch immigrants preferred English language journals and the paper suffered a steady decline in circulation. By 1990 it was fortnightly and by the time it ceased publication, in October 2004, it was monthly. Its last editor was Wabe Roskam. 
The Dutch Australian Cultural Centre, a repository for postwar Dutch immigrant archival material (http://www.dacc.com.au), was founded in December 1982.

\section{Choral groups}

Sydney has had several important Dutch choral groups. The Dutch Choir and Folkloric Group Dee Why, under Isidoor Lammers, was formed by 25 Dutch parishioners of the Dee Why Presbyterian Church in 1958. Originally performing purely liturgical functions, it later participated in the Shell Folkloric Festival, the Warringah Eisteddfod, Carnivale, Carols by Candlelight and the Holland Festival. Unfortunately it is now defunct. The Sunrise Choral Society was formed in Blacktown in 1959 under the name 'Morgenrood' and is still in existence. Initially, its entire repertoire was in Dutch, but as numerous non-Dutch singers joined, it became increasingly anglicised. Nevertheless, the society is strongly identified with Dutch cultural events, such as the Bowral Tulip Festival. In 1985, some of its members - who were also members of the Rembrandt Dutch Club in St Marys - formed the Rembrandt Male Choir under Harry Joosten. Today this choir has Australian, Welsh and German-born members among its Dutch ranks, but all are committed to singing songs in the original language of composition.

\section{Sport}

Many Dutch immigrants (like those from other parts of the world) came to Australia with sporting credentials established in Europe, and helped to make Australia a formidable sporting nation in the 1950s and 1960s. In the Netherlands, soccer (like cycling) is a national passion. Dutch soccer enthusiasts did much to help challenge the hold that Rugby and Australian Rules have historically had in Australia. This has mainly been through the establishment of the Sydney Austral club. After it disbanded in 1969, many of its players joined Western Suburbs.

\section{The Dutch contribution to Sydney}

A succession of early Dutch immigrants played strong pioneering roles as entrepreneurs and manufacturers in Australian centres. Issac van den Broek established a boot-uppers factory in Sydney in the 1860s. William Paling (born Rotterdam, 1825), who arrived in Sydney on the Clir in 1855, established a highly successful music store in George Street and was a foundation director of the Mercantile Mutual Insurance Company. Sampson de Groen (1839-1883) who arrived from Rotterdam on the Light of the Age in 1858 established a very successful clothing store opposite Sydney Town Hall. His son achieved local fame with his de Groen's Vice Regal Band.

In December 1926, Phillips Industries established an Australian subsidiary in Sydney under the direction of Anton den Hartog with a staff of seven men in small rooms in Margaret Street. It imported lamps, X-ray tubes, radios, radio components and battery chargers. In 1929, the 
company took over a former car-body works in Camperdown and assembled radios and radio kits, later making radio valves. During World War II, Phillips played a vital part in the manufacture of navigational and electronic instruments essential for the armed forces and the defence of Australia. Unfortunately, Phillips is no longer a manufacturer in Australia. Anglo-Dutch group Shell has had a presence in Sydney since 1901 and has operated the Clyde refinery since 1928.

The Dutch in Sydney have made a vast contribution. Thousands of skilled Dutch tradesmen and technicians helped to breathe new life into Sydney's postwar industries. The Dutch established enterprises of their own, particularly in the building and horticultural fields. Furthermore, steeped in the cultural heritage of the Netherlands they enriched Sydney's cultural life with new and varied forms of expression.

There are around 20,000 Dutch-born residents of New South Wales and over 65,000 of Dutch descent, most of whom live in Sydney. Prominent postwar Dutch Sydneysiders have included 'Dick' (Gerardus Josef) Dusseldorp (died 2000), founder of Lend Lease; Edo de Waart, long serving conductor/artistic Director of the Sydney Symphony Orchestra (1993-2003); Paul Couvret, four times Shire President of Warringah (1979-1983); Annita Keating van Iersel (born 1948), former wife of Prime Minister Paul Keating, whose command of five languages proved an invaluable diplomatic asset, especially in support of Sydney's bid for the 2000 Olympic Games; Gerard Havekes (born 1925) who sculpted the monolithic 'FJ Walker Fountain' in Hyde Park; and Hendrik Kolenberg (born 1946) Senior Curator at the Art Gallery of New South Wales.

Edward Duyker is a Sydney writer and historian.

\section{References}

Edward Duyker, The Dutch in Australia, AE Press, Melbourne, 1987

Edward Duyker, Early Dutch Immigrant Naturalizations: An Alphabetical Index 1843-1903, Vol I (Victoria, New South Wales \& Queensland), privately published, Sylvania, NSW, 1987

M Hage, (ed) Short History of and Information on Netherlands Societies in New South Wales and the Australian Capital Territory, Federation of Netherlands Societies, Sydney, 1985

E Keane, Music for a Hundred Years: The Story of the House of Paling, Oswald Ziegler Publications, Sydney, 1954

JS Levi, The Forefathers: A Dictionary of Biography of the Jews of Australia 1788-1830, Australian Jewish Historical Society, Sydney, 1976

M Murphy, Challenges of Change: The Lend Lease Story, Lend Lease, Sydney, 1984 
P van Os, Reis naar Nieuw-Zuid Wallis Nit he Dagboek van een Scheepsdoctor voor de jeugd bewerkt, van Druten \& Bleeker, Netherlands, c1853

LL von Münching 'De geschiedenis van de Java-Austalië Lijn van de KPM', De Blauwe Wimpel, vol 55 no 1, 2000 